\title{
THE SPREAD OF THE SEA LAMPREY THROUGH THE
} GREAT LAKES.

\author{
Carl L. Hubbs \\ Division of Fishes, Museum of Zoology, University of Michigan, \\ Ann Arbor, Michigan \\ and \\ T. E. B. POPE

\section{Milwaukee Public Museum, Wisconsin}

In the Great Lakes the sea lamprey (Petromyzon marinus) has been known, until recently, only from Lake Ontario and tributary waters below Niagara Falls. As a considerably dwarfed form, the species occurs naturally and abundantly in that lake, and in the Finger Lakes of New York (Gage, 1893 and 1928; Surface, 1898 and 1899; Huntsman, 1917 ; Dymond, Hart and Pritchard, 1929).

These authors have stressed the predatory destructiveness of the sea lamprey in Cayuga Lake and Lake Ontario. This eel-like creature, averaging about fifteen inches long, when mature, clings to the larger food fishes with a round sucker-mouth, beset with rows of strong, horney teeth; then rasps open a hole in the skin of its victim by means of its serrated tongue plates, and injects an anticoagulating substance into the wound, to insure the free flow of the victim's blood, with which the parasite gorges itself. A considerable proportion of the lake trout, northern pike, bullheads, carp and other fishes in Lake Ontario and the Finger Lakes are reported to bear lamprey scars. The blood-sucking attacks no doubt have a harmful affect on the host fish, and victims of heavy lamprey attacks are occasionally found dead. In Lake Ontario the lampreys even torment swimmers, though there seem to be no records to indicate that they have injured a human being.

The fish of Lake Erie, Huron, Michigan and Superior until very recently seem to have been spared from the attacks of this vertebrate parasite, though they have been less seriously attacked by two smaller native species, of the genus Ichthyomyzon. ${ }^{1}$ This freedom from attacks by the sea lamprey may to a small degree have been responsible for the large production of fish in these waters, particularly in Lake Erie.

The failure of the landlocked sea lamprey to ascend Great Lakes waters above Lake Ontario has doubtless been the insurmountable obstacle of Niagara Falls (Huggs and Brown, 1929:3). Though lampreys can make their way over steep falls, clinging to the rock walls with their sucking mouths, the Niagara escarpment has presented an im-

Bensley'g 1915 bearsay report of Petromyzon marinus from Georglan Bay we now belleve was based on a native lamprey (Ichthyomyzon). 
passably high barrier. Man-made canals, however, now afford a means by which the sea lamprey and other Lake Ontario fishes can by-pass the great falls. Hubbs and Brown (1929:'17) wrote:

"The occurrence of the sea lamprey in Lake Erie is a recent discovery. The specimens collected at Merlin, November 8, 1921, were the first for the lake to be scientifically reported (Dymond, 1922, p. 60). Dr. John Van Oosten in the fall of 1927 saw one which had been caught near Sandusky and W. M. Tidd collected one there in the spring of 1928. At the same place Prof. E. L. Moseley saw another about two weeks before Mr. W. D. Bates sent us the specimen from near Rondeau. ${ }^{2}$ Mr. Bates told Dr. Van Oosten that he occasionally takes the large lamprey in his nets.

"There can be little question as to the recentness of the establishment of the species in Lake Erie. That it immigrated into Lake Erie from Lake Ontario through Welland Canal is extremely probable. Since the species is much larger than the native lamprey of Lake Erie, Ichthyomyzon concolor, and is known to be very destructive to food fishes in Cayuga Lake, New York, and elsewhere, its establishment in Lake Erie adds another potential factor to those responsible for the depletion of the great fisheries of this important lake."

Osburn, Wickliff and Trautman (1930) reported the early taking of another sea lamprey in Lake Erie, one caught near West Sister Island, Ohio, on November 14, 1927.

The first definite indication of spawning runs by the sea lamprey of Lake Erie was furnished by Creaser (1932:157), who wrote:

"This lamprey has now penetrated the waters of Lake Erie to one of its western tributaries in the State of Michigan, the Huron River, where an adult specimen was collected at Flat Rock on May 8, 1932. This constitutes a new record for the state (the specimen has been examined), and is an indication of the complete establishment of this lamprey in Lake Erie. The way is now open for a further penetration into Lake St. Clair and Lake Huron. In the not too distant future, it will no doubt be encountered throughout the Great Lakes waters. Knowing its record of destruction among the food fishes of Cayuga Lake in New York, we must consider it as one more source of further depletion of the fisheries of the Great Lakes. The sea lamprey and the smelt (Osmerus mordax), which has recently spread over a great portion of Lake Huron and Lake Michigan, will act as great disturbers of the natural balance of the large fisheries of these extremely productive lakes, which are already in much distress."

More recently, mature sea lampreys have been taken by the Campbell brothers in Swan Creek, a tributary of the Maumee River in Troledo, Ohio, among mature native lampreys. One $455 \mathrm{~mm}$. long, was collected May 8, 1934, and two others, respectively 459 and $528 \mathrm{~mm}$. long, on April 26, 1935. No doubt the species is reproducing in some numbers in the streams tributary to Lake Erie.

By 1930, the sea lamprey had considerably increased in western Lake Erie, and had already made its way beyond that lake. In the second week of May of that year Mr. Melbourn Heubner of Detroit, while fishing in the St. Clair River, caught a sea lamprey, recognizable

Thio opecimen, taken at Polnte Aux PIns opposite Rondeau Harbor, Ontarlo, weo $560 \mathrm{~mm}$ (twenty-two laches) long, larger than ang recorded from Lake Oatario. 
as such from a colored sketch which he made. This lamprey, thirteen and three-fourths inches long, was attached to the side of a four and one-half pound pike-perch.

Until this year (1936) no further extension of the range of the sea lamprey into the Great Lakes came to our attention, but the pest was undoubtedly dispersing through Lakes Huron and Michigan, probably even breeding in small numbers in creeks tributary to these lakes.

As indicated in Wisconsin and Michigan newspapers, and The Fisherman for June, 1936, Capt. Frank C. Paczocha of Milwaukee brought to the Milwaukee Public Museum on March 23, 1936, a sea lamprey sixteen inches long, which he had taken the previous day while fishing in Lake Michigan about fifteen miles east of the city. It was attached to a four and one-half pound lake trout, just below the eye of the fish. Though this fishernian had frequently seen other lampreys on fishes, they were usually much smaller, and presumably of the native species.

The establishment of the sea lamprey in Lake Michigan was confirmed soon afterward, for a male apparently on its spawning run was captured at Elk Rapids, Michigan, on the afternoon of June 13, 1936. This specimen, fifteen and one-half inches long when fresh, was taken by R. B. Zupin, who turned it over to Conservation Officer Mark Craw, who in turn presented it, with appropriate information, to the University of Michigan. Mr. Craw stated that the creature must have come in from the East Arm of Grand Traverse Bay, and that it was found working its way against a swift current in the outlet of Elk Lake, in the spillway behind the Michigan Public Service Company's plant.

The sea lamprey is no doubt not only spreading but also increasing in numbers in the Great Lakes. There is good reason to expect that it will follow the history of the smelt, eventually reaching to the limits of the Great Lakes and greatly increasing in numbers. The multiplication of the lamprey has been at a slower rate than that of the smelt, and will continue so, because the life cycle is much longer: Gage (1928) estimates the larval life of Petromyzon as four or five years, and the immature period of adult life as one and one-third to three and onethird years; the smelt spawns when only 2 years old. On account of its slow turn-over, the lamprey will not likely increase alarmingly for several years. In time, however, the sea lamprey may well attain an abundance equal to or greater than that maintained in Lake Ontario and in Cayuga Lake. If that not improbable end be reached, this large and destructive blood-sucking parasite will justify the fears expressed by Hubbs and Brown and by Creaser, quoted above, that it will add one more very serious factor to those already seriously depleting the supply of lake trout, whitefish, suckers, catfish and other commercial fishes in the Great Lakes.

It is doubtful that any attempt to curtail the increase of sea lampreys would prove practicable. At great effort the increase might be retarded, though probably not prevented. As the species becomes abundant enough 
to produce definite spawning runs, however, definite control measures may become more effective. The New York investigators, Surface and Gage, point to the spawning run as the most vulnerable period in the sea lamprey's life cycle, for large numbers may then be caught as they move upstream into creeks, or as they build their nests and spawn.

For the present, attempts to control this unwanted and destructive immigrant into Great Lakes waters would seem practically limited to the killing of all individuals caught by fishermen.

To help in further tracing the spread and increase of the sea lamprey in the Great Lakes, specimens caught should be reported, with data as to place and date of capture, and with a statement of the size, color and shape of the fins. The landlocked sea lampreys when adults are usually thirteen to twenty-two inches long, averaging about fifteen inches, while the native lampreys of the Great Lakes other than Lake Ontario almost never exceed thirteen inches and probably never reach fifteen inches in length; the sea lampreys are strongly mottled with dark and light colors, while the native lampreys are almost or quite uniform in coloration; the dorsal fins of the sea lamprey are separated from one another, rather than joined together to form a single fin, and the dorsal and caudal fins are angular rather than rounded, as they are in the native forms. Although these characters will serve to distinguish the sea lamprey from the species naturally occurring in the Great Lakes, it would be helpful and more definite to have specimens sent in for identification. If possible they should be preserved (preferably in formalin, one part to ten of water). A watch should be maintained for spawning runs, which when found should be made known. All such information and specimens may be sent to the University of Michigan Museum at Ann Arbor, to the Milwaukee Public Museum, or to the appropriate state or provincial department of conservation.

\section{Literature Cited}

Bensley, B. A.

1915. The fishes of Georgian Bay. Contr. Can. Biol., 1911-1914: pp. 1-151, figs. 1-5, pls. 1-2.

Creaser, Charles W.

1932. The lamprey Petromyzon marinus in Michigan. Copeia, 1932, No. 3 : 157.

Dymond, John R.

1922. A provisional list of the fishes of Lake Erie. Publ. Ont. Fish. Res. Lab., No. $4:$ :55-74.

Dymond, J. R., Hart, J. L., and Pritchard, A. L.

1929. The fishes of the Canadian waters of Lake Ontario. Publ. Ont. Fish. Res. Lab., No. 27 : 1-35, 1 graph. 
Gage, Simon Henry

1893. The lake and brook lampreys of New York especially those of Cayuga and Seneca lakes. Wilder Quarter-Century Book: 421-493, pls. 1-8.

1928. The lampreys of New York State. Life history and economics. In: A biological survey of the Oswego River system, Suppl. to 17th Ann. Rep. N. Y. Cons. Dept., 1927: 158-191, figs. 1-7, col. pls. 1-2, 1 fig.

Hubbs, Carl L., and Brown, Dugald E. S.

1929. Materials for a distributional study of Ontario fishes. Tran. Roy. Can. Inst., vol. $17: 1-56$.

Huntsman, A. G.

1917. The lampreys of eastern Canada. Ottawa Nat., vol. 31: 23-27.

Osburn, Raymond C., Wickliff, Edward L., and Trautman, Milton B.

1930. A revised list of the fishes of Ohio. Ohio Jour. Sci., vol. 30:169-176.

Surface, H. A.

1898. The lampreys of central New York. Bull. U. S. Fish Comm., vol. 17, 1897: 209-215, 2 figs., pls. 10-11.

1899. Removal of lampreys from the interior waters of New York. 4th Ann. Rep. Comm. Fish, Game and Forests, N. Y.: 191-245, 6 pls.

\section{Discussion}

Dr. Leon ard P. Schultz (Washington): Lampreys are of some value in that the larvae can be dug from the mud in the streams and used as bait. In the state of Washington a man I knew took several thousand lampreys and sold them as bait for bass and other fish, and told me he made about $\$ 3,000$ that year. On the other hand, once in a while these lampreys are eaten by other fishes; we have found several of the marine fish with lampreys in their stomachs. I do not know whether that occurs in the Great Lakes or not. 